\title{
How to Promote Healthier Shopping Behaviour: Which Are the Most Effective Retail Marketing' Levers in E-Commerce Grocery
}

\author{
Silvia Bellini ${ }^{1}$, Simone Aiolfi ${ }^{2} \&$ Maria Grazia Cardinali ${ }^{3}$ \\ ${ }^{1}$ Department of Economics and Business Management, University of Parma, Italy \\ Correspondence: Simone Aiolfi, Department of Economics and Business Management, University of Parma, \\ Italy. E-mail: simone.aiolfi@unipr.it
}

Received: December 4, 2020

Accepted: January 10, 2021

Online Published: February 22, 2021

doi:10.5539/ijbm.v16n3p101

URL: https://doi.org/10.5539/ijbm.v16n3p101

\begin{abstract}
The World Health Organization (WHO) suggests people to eat at least five portion of fruits and vegetables a day, but the level of consumption of this category is far from been reached. Considering that the majority of food purchases occurs in grocery context, increasingly in e-commerce channels, understanding how retailers could improve food choice, both in physical and digital stores, is paramount to healthier living. This paper aims to understand which are the most effective retail marketing' levers in stimulating impulse buying in fruits and vegetables category, therefore in promoting healthier shopping behavior. Since fruit and vegetable is known for its healthy vocation and its role in differentiating and enhancing the perceived image of retailers, this category is the ideal place to host nutritional marketing initiatives. We used a quantitative survey method to explore shoppers' behaviour in an online setting, focusing on fruit and vegetables' category. Respondents were exposed to nine marketing stimuli, according to different communication contents (price versus non price). All the data was considered for linear regression analysis. Our results show that the pre-shopping preparation has an effect on purchasing behaviour, limiting its impulsiveness. Furthermore, price levers and communication levers influence the intention to buy impulse in the online channel, with the latter more effective than the other ones. Therefore, as this process takes place in the digital context, marketing efforts need to focus on dimensions that increase the propensity to make impulse purchases online: communicative and price stimuli.
\end{abstract}

Keywords: impulse buying, nutritional marketing, shopper marketing, online, fruit and vegetables

\section{Introduction}

The retail landscape, in recent years, has undergone major transformations both in the perspective of retailers and in the consumer perspective. On the firms' perspective, retailers are forced to manage the new challenges due to increasing digitalization and technological evolution, including the diffusion of mobile connectivity. Therefore, retailers have to manage their business in a context of competitive convergence, hybridization of store formats, and continuous expansion of online channels in the emerging omnichannel retail setting (Bell, Corsten, \& Knox, 2013; Brynjolfsson, Hu, \& Rahman, 2013; Lewis, Foster, \& Whysall, 2013; Strang, 2013; Beck \& Rygl, 2015; Cardinali \& Bellini, 2014; Herhausen, Binder, Schoegel, \& Herrmann, 2015; Aiolfi \& Sabbadin, 2017; Cardinali, 2018). On the other hand, consumers, increasingly informed and constantly connected, try to reacts to the economic crisis by changing their consumption and purchasing behaviours, towards greater planning and a more sustainable and healthier consumption and lifestyle (Bellini, Cardinali, \& Grandi, 2017).

That said, today, the major challenge for retailers is to achieve a distinctive positioning in the mind of consumers. This is possible by managing all the levers of the retail mix in an innovative way. The analysis of demand and its evaluation criteria is a fundamental prerequisite for designing and implementing appropriate marketing strategies that take into consideration the transformations that have characterized the economic environment in the recent decade. It is essential to understand in which direction demand is moving, reaching customers among different channels, giving them a seamless shopping experience. Moreover, retailers have not to forget to respond with an offering suitable to meet new consumers' habits such as a sustainable and healthy lifestyle.

Literature show several marketing contributions regarding the analysis of consumers' decision-making process, as evidenced by the numerous studies of consumer behaviour from the 1950s until today day (Kollat \& Willet, 1967; Iyer \& Ahlawat, 1987; Iyer, 1989; Inman, Winer, \& Ferraro, 2009; Hulten, 2012; Mohan, Sivakumaran, \& Sharma, 2013; Shankar, 2014; Wiese, Zielke, \& Toporowski, 2015; Bellini, Cardinali, \& Grandi, 2016; Bellini \& Aiolfi, 
2017 and 2019). However, the theoretical background on buying behavior is less numerous and more recent. Since the 1990s, marketing literature has begun to highlight the importance of in-store shopping behaviour. Many researchers support the idea that consumer engagement within the store has not only a rational dimension, but also an emotional one (Hirschman \& Holbrook, 1982). In this context, the store begins to be considered as a means of communication, an environment that produces sensory stimuli (Donovan, Rossiter, Marcoolyn, \& Nesdale, 1994), capable of reminding consumers of temporarily forgotten needs, suggesting or stimulating latent needs or even stimulating new purchases or purchases not previously planned (Inman et al., 2009). The branch of literature that focuses on the influence of in-store marketing levers on shopper behavior is known as 'shopper marketing' (Cardinali, 2009; Shankar, 2011). There have been several contributions both on the topic in general and on the specific marketing levers managed by retailers. In this context, some authors began to recognize that many purchasing decisions are not made before consumers enter the store (Inman et al., 2009) and began to define and analyse the phenomenon of impulse buying (Kollat \& Willet, 1967; Iyer \& Ahlawat, 1987; Iyer, 1989; Beatty \& Ferrell, 1998; Inman et al., 2009; Hulten, 2012; Mohan et al., 2013; Muruganantham \& Bhakat, 2013; Shankar, 2014; Venkateswara, Kumar, \& Srinivasa, 2015; Wiese et al., 2015; Bellini et al., 2016; Bellini \& Aiolfi, 2017 and 2019). In marketing literature, considerable efforts have been made in identifying factors that influence impulse buying in the offline channel (Kollat \& Willet, 1967; Iyer \& Ahlawat, 1987; Iyer, 1989; Beatty \& Ferrell, 1998; Inman et al., 2009; Hulten, 2012; Mohan et al., 2013; Muruganantham \& Bhakat, 2013; Shankar, 2014; Venkateswara et al., 2015; Wiese et al., 2015; Bellini et al., 2016; Bellini \& Aiolfi, 2017 and 2019).

Different the situation for the online channel. Although with technological progress and the growth of e-commerce, online impulse purchases have become part of individuals' daily lives, there are still few efforts to consolidate previous knowledge in the context of online impulse purchases (Verhagen \& Van Dolen, 2016; Chan, Cheung, \& Lee, 2017). It is clear that offline searches do not apply directly to the online channel, which has completely different characteristics. It is estimated that the online shopping environment is better suited to conduct impulsive shopping behaviours than the offline one (Chan et al., 2017).

Given the importance of this area of research, both for retailers and manufacturers, we decided to investigate the online determinants of the buying behaviour declined to grocery industry. In fact, while traditionally consumer products have always been purchased in physical channels, today the situation is different. Most of the large grocery retailers on the international and national scene are moving towards an omnichannel approach (Aiolfi \& Sabbadin, 2017). The big offline players have implemented their channel strategy, entering the online and on the other side big pure players, born online, have landed on the physical channel. A recent research by Statista (2020), states that the e-commerce channel will reach an overall global turnover of approximately US $\$ 599.1$ billion by 2024 in the U.S. and of US $\$ 503.0$ billion by 2024 in Europe. The challenge today is to be able to understand which marketing levers best work in influencing the buying behaviour of the online consumer.

For all these reasons, we decided to investigate the buying behaviour of the shopper in the online context focusing specifically on the fruit and vegetables. The choice of this category, as well as the analysis of the characteristics of the grocery sector, are consistent with the growing demand for health and well-being manifested by individuals and the growing importance of nutritional marketing assumed in retailing. In fact, retailers have been in a precarious position regarding public health over the past decade. Most of the adults are overweight or suffer from obesity. At this point, many accusations have been made against the grocery sector and retailers have also been called upon to resolve this public health problem. Although the latter were active in educating shoppers, explaining the nutritional profile of their products or implementing the assortment with healthier products, initially the results showed a small contribution in improving the purchase and consumption, among individuals, of fruits and vegetables. As Bellini (2017) points out, the very nature of the fruit and vegetables leads to the belief that sales should be improved with the management of no-price levers. In fact, the comparability of the assortment and the consequent ability of the consumer to assess affordability is limited by at least three factors: the variability of quality, the reduced presence of the brand and, consequently, the lack of an anchor price. Other studies confirm that variables such as price and promotion are not suitable to support category sales; instead, variables such as assortment and merchandising, supported by communication and information strategies, are the offline variables that help define impulse purchases (Payne, Niculescu, Just, \& Kelly, 2014).

From this starting point it is possible to frame the current situation in order to understand which or what will be the most relevant variables that affect shoppers in making impulse purchases while buying fruit and vegetables online. Our research focuses on the online channel with the belief that consumers behave differently when buying fruit and vegetables online than the offline channel, preferring more impulse behaviour. However, it remains difficult to predict which marketing levers will influence the consumer in making impulse purchases. 
For these reasons, two topics caught our attention. First, we studied people's attitude and interest in the purchase of fruit and vegetable. Second, we defined which stimuli affect impulse purchases for fruit and vegetables according to different types of communication and advertising.

The paper is organized as follows. First, a literature review about new challenges in retailing and impulse buying is presented (par. 2). Secondly, we present our research objectives (par. 3) and the methodology used (par. 4). Then, we present and discuss our findings (par. 5). Finally, the last two sections are devoted to conclusion and managerial implications (par. 6), limitations and future directions (par. 7).

\section{Literature Review}

In the last decade, there has been significant changes in grocery retailing. First, as far as the structure of the retail market, the decline of large formats in favour of the growth of small and medium-sized formats and the hybridization of formats as well as the expansion of channels are the main changes of nowadays. Second, retailers are moving towards an expansion of the target market and the development of new strategies in order to capture competitors' customers (Cardinali \& Bellini, 2014).

What emerges from these changes are both the rise of 'hybrid formats' that combine features of different store formats (Cardinali \& Bellini, 2014) and the development of an omnichannel retailing approach. In literature, the term omnichannel states for the set of activities involved in selling merchandise or service through all widespread channels at the same time with full interaction triggered by customer and full integration controlled by retailer (Beck \& Rygl, 2015). In the omnichannel approach, customers are able to exploit simultaneously physical and virtual touch points, information and transactional channels that can respond more appropriately to the different needs of consumers at various stages of the purchasing process (Rangaswamy \& Van Bruggen, 2005). Therefore, it is increasingly difficult to understand the boundaries among cannels and geographical and information barriers begin to disappear (Verhoef, Kannan, \& Inman, 2015).

In order to manage the new online competition and establish a long-lasting relationship with consumers, the most innovative retailers have revised their presence in the market, increasingly moving towards the implementation of channel diversification policies, in order to improve their brand identity.

It is essential that retailers become aware that the choice of the retailer, on consumers' perspective, has changed. If in the past, retailers attracted customers with exclusive assortments and ever-improving services, today, the assortments and services of many retailers are increasingly similar. To achieve a more competitive position in the minds of consumers, retailers must also manage other levers (in-store marketing, services, technologies and advertising), in addition to traditional ones, focusing on the differentiation of the company through the management of retail mix levers in an innovative key (Bellini \& Cardinali, 2015; Bellini, 2017).

Moreover, in recent years, changes in consumer purchasing behaviour, generated by the increasing use of digital technologies in purchasing processes, have led to a further intensification of attention towards possible strategies aimed at influencing consumer choices (Shankar, 2011). Therefore, the analysis of demand must take into account all the phases in which the decision-making process is carried out: the cognitive processes that precede the act of purchase and which relate to the formation of needs, the search for information and the evaluation of alternatives; the behavioural processes that give rise to purchasing decisions. However, the growing importance of the behavioral dimension does not overshadow the cognitive dimension, which, thanks to the spread of digital technologies, and their use in the pre-purchase process has been enriched with new elements of complexity (Bellini \& Aiolfi, 2017 and 2019).

In order to fully understand the extent of recent changes in the shopper marketing scenario, it is appropriate to start from the theoretical framework of purchasing behaviour and the determinants that qualify its nature between programmed and impulse, recognizing that many purchasing decisions are not made before consumers enter the store (Inman et al., 2009; Bellini, 2017).

The first structured classification of purchasing behaviour was due to Stern's work (1962) which distinguished purchases into three categories: 'planned purchase', 'unplanned purchase' and 'impulse purchase'. The difference between these cases lies in the emotional involvement of the consumer (Bellini, 2017). A 'planned purchase' is characterized by careful and deliberate research and evaluation that normally leads to rational, accurate and better decisions (Halpern, 1989; Hosmer \& Lemeshow, 1989). Conversely, an impulse purchase involves a spontaneous and immediate purchase (Rook and Fisher, 1995) where the consumer is not actively looking for a product or has not previously planned to purchase (Beatty \& Ferrell, 1998). As far as spontaneity, Rook (1987) described impulse buying as an intuitive and exciting urgency to buy without regard to the consequences of purchasing decisions. In addition, Lee and Kacen (2008) identified the main differences between planned purchases and impulse purchases 
for information that consumers can search for before purchasing and in the time spent during the decision-making process. D'Antoni and Shenson (1973) described those differences by explaining that as far as impulse purchase, consumers process fewer information and therefore take little time to decide towards purchases, whereas in the planned purchase the time taken for the same purchase decision is greater.

Initially, academic interest in impulse buying mainly concerned sales of products and early studies focused only on purchases, without investigating consumer characteristics and their emotional and cognitive reactions (Abratt \& Goodey, 1990; Muruganantham \& Bhakat, 2013). Then, Rook (1987) stated that during an impulse purchase consumers live an instant, dominant and persistent desire. Subsequently, Rook and Gardner (1993) defined impulse buying as an unplanned behavior that implies a quick decision-making process towards the immediate purchase of the product. This was also confirmed by Block and Morwitz (1999) and Beatty and Ferrell (1998). In addition, Kacen and Lee (2002) pointed out that impulsive behavior is more exciting and irresistible, but less deliberate when compared to planned buying behavior. Finally, according to Engel and Blackwell (1982), impulse purchase is an action taken without first being consciously recognized and without preparation before entering the store. Muruganantham and Bhakat (2013) concluded that impulse purchases include hedonic purchasing decisions made within the store and that exclude buying activities with stimulated recall. On the other side, planned purchases can be defined as purchases whose decision is made by shoppers before entering the point of sale and which is characterized by an intention to buy before being influenced by in-store stimuli (Bellenger, Robertson, \& Hirschman, 1989).

Impulse purchases can be divided into four categories (Han, Morgan, Kotsiopulo, \& Kang-Park, 1991): 'planned impulse buying' that refers to partially planned purchases for which shoppers before entering the store already have a general intention to buy as far as category or product; however the specific item is decided within the store, once the shopper is subjected to the in-store stimuli (price, promotions or visibility of products); 'reminded impulse buying' that refers to hybrid form of impulse purchase as it does not originate from a new need stimulated in-store, but from an unconscious or latent need that 'wakes up' in-store thanks to the stimuli promoted by retailers; 'suggested impulse buying' that occurs when consumers are buying products that they do not have planned before (but a certain need already exists) and whose usefulness and functionality are learned only once they enter the store; 'pure impulse buying' that is characterized by a complete absence of planning, originating from a sudden and irresistible desire that pushes to immediate action without a rational decision-making process (Bellini \& Aiolfi, 2017 and 2019).

Finally, recent studies on impulse buying shift the focus from the role of products to consumers, recognizing that it is then individual, not products, who lives the experience of an impulsive desire to buy and/or consume. Following this perspective, recent works contribute to the analysis and discussion of determinants of impulse buying especially in the offline context (Tinne, 2010; Muruganantham \& Bhakat, 2013). The main explanatory variables of impulse purchase can be divided into two macro-areas: internal variables and external variables (Raju, Kumar, \& Raju, 2015).

External variables refer to product-related factors (e.g. nature and specific characteristics of products), situational stimuli and instore-related factors controlled by retailers that can act on the physical (real or perceived) context in order to create stimuli that can engage the impulsiveness of shoppers (e.g. store atmosphere, in-store marketing activities) (Hoch \& Lowenstein, 1991). Internal variables refer to sociodemographic characteristics, attitude towards shopping and individual personality traits.

To date, with the improvements in information technology and the growth of e-commerce and m-commerce, online impulse purchases have become part of individuals' everyday life. Specifically, it has been estimated that about 40 percent of online consumer spending is due to impulse buying (Liu, Li, \& Hu, 2013). Literature argues that the online shopping environment leads to more impulse purchases than the offline one, as the online environment let consumers free from many of the constraints they might experience when shopping offline. As a result, online impulse buying is gaining more attention from the academic community. However, contributions on this topic remain few date (Chan et al., 2017). As for the offline channel, in the online environment there are two types of variables that trigger impulse purchases: external and internal stimuli. The internal stimuli are the same as the offline channel, while external stimuli differ between the two channels and relate to 'website stimuli', 'marketing stimuli' and 'situational stimuli' (Chan et al., 2017).

'Website stimuli' include website features (visual aspects, navigability, display adaptability, ease of use), online payment systems, persuasive claims (scarcity, popularity) and variables related to website interactivity (Gwee \& Chang, 2013; Chan et al., 2017). Particularly, Adelaar, Chang, Lancendorfer, Lee and Morimoto (2003) studied the display formats (text, images and videos) of a virtual store and explored their effects on consumers' emotions 
and impulse purchases. These experimental settings allowed researchers to draw conclusions about the effects of particular website features on impulse purchase.

'Marketing stimuli', which offline represent in-store marketing actions, online include the same marketing levers as the online site's functionality. For example, as far as the assortment and 'space allocation', content can be organized by information category, by user type, by date, by nationality; as far as price and promotions, it is possible to manage a price discrimination policy (e.g. better prices to loyal customers, higher prices if demand is growing, lower prices if the stock is high). In addition, online, retailer have to work on the socialization of the experience (reviews, rankings, community, etc.) in order to influence the evaluation of products and retailers. Marketing stimuli also include variables related to the sales environment, which online is represented by website architecture. This could affect the searching costs for information (time, frustration, risk of cart abandon), the cost of not finding information (the company's image is perceived negative and users switch to competitors' sites), the costs of reputation (the crash of the website influences the reputation of the retailer), the value of the brand (a good site improve the perception of the brand and the credibility of the company) and the value of the relationship (the site is the interface between customer and company, it lays the foundations for a good relationship in the future) (Bellini, 2017).

Finally, 'situational stimuli' are the social or environmental factors associated with a particular occasion of consumption that can influence the consumer's purchasing response. These stimuli can increase or decrease impulsive propensity to buy. Although situational stimuli have been widely studied in the online context, there are few studies on the topic of online impulse buying (Chan et al., 2017). However, an interesting contribution by Zhang, Zhou, Uchidiuno, \& Kilic (2017) focus on the relationship between online browsing and impulse shopping. Previous research by Verhagen and van Dolen (2011) showed that online browsing activity was positively correlated with the consumer's urgency in making impulse purchases. In fact, as Zhang et al. pointed out (2017), online browsing takes time, so it is possible that during the activity the consumer impulsively perceives the urgency of buying something. Previous research has shown that, compared to shoppers who have precise purchase plans, those who proceed with the browsing activity are more likely to make unplanned purchasing decisions, as they are more receptive to environmental influences (Moe, 2003).

\section{Research Objectives}

In recent years, the relationship between Italians and food has changed in favour of a mature awareness of the link between eating and health. Therefore, the growth in nutritional demand opens up extraordinary opportunities for innovation for retailers that want to reconfigure their image in a distinctive way. In fact, retailers should exploit their strong influence on consumer food choices by manipulating the marketing in-store levers in a nutritional perspective (Payne et al., 2014). For example, it is possible to revise the assortment in a nutritional way introducing health and wellness segments such as organic, wholegrain, fruits and vegetables. Retailers, leveraging new styles of consumption, can identify new paths of innovation aimed at achieving two objectives: to give distinctiveness to the retailer itself in order to get out of the trap of channel convergence and at the same time to enrich the shopping experience by working on the 'shopping enjoyment' that improves affection towards the retailer and increases the intention to buy impulsively (Bellini, 2017).

Specifically, fruit and vegetables stands out from the other sectors by its important contribution to corporate profits and its nutritional vocation. On one side, fruit and vegetables products are sold at a relatively high operating margin, as can be seen by comparing its contribution to retailers' turnover and profits (Payne et al., 2014). On the other hand, these products not only contribute to weight loss, but also bring health benefits (Casagrande, Wang, Anderson, \& Gary, 2007). Moreover, fruit and vegetables is not the ideal setting for developing price promotions, and price lever is not best suited to support the department's sell-out (Talukdar \& Lindsey, 2013). Talukdar and Lindsey (2013) highlight how the elasticity of demand for healthy foods is greater for increases than reductions. This is because consumers' expectation for healthy foods is that they are less tasty, so a price reduction is not enough to significantly increase demand. Different is for unhealthy foods, where demand sensitivity is higher for reductions than increases. Consumers in this case expect healthy foods to be better and therefore they respond promptly to a price reduction rather than to a price increase. As a result, the low elasticity of demand of healthy foods to the downside of prices leads to the belief that sales in fruit and vegetables should be supported with the use of non-price levers (Lugli, 2015; Bellini, 2017). In addition, the comparability of assortments and the consequent ability of consumers to assess affordability is limited by at least three factors: the variability of quality, the reduced presence of the brand and, consequently, the lack of an anchor price. Furthermore, fruit and vegetables are a category highly linked to seasonality and weather conditions, which can affect the presence of the product in store. As a result, it is difficult for retailers to plan promotions in advance and define the percentage of effective and sustainable price reduction. It must also be considered that fruit and vegetables are not stockpiling, so it is not 
possible to imagine that consumers will increase consumption of products in order to seize the promotion. Moreover, it may happen that promotion with even significant discounts on specific products may not be attractive to those who do not use such products, since tastes of consumers are well defined (Lugli, 2015). However, increasing variety of fruit and vegetables is an effective strategy if retailers want to increase consumers' propensity to consumption of those products and to promote health. In fact, the extension of the range and variety of the assortment, supported by a clear segmentation, makes offerings easily readable. At the same time, increasing the amount of space dedicated to fruit and vegetables can be a way to enhance the healthy image of retailers, without necessarily an increase in sales or margins in the short term (Bellini, 2017). Therefore, even the very nature of the fruit and vegetables leads to confirm that sales should be supported with the use of levers different from that of price. Variables such as assortment and merchandising, supported by communication and information strategies, are the variables that help define impulse buying offline and that allow retailers to differentiate themselves and create both a distinctive image and a unique shopping experience (Payne et al., 2014; Bellini, 2017).

To sum up, fruit and vegetables plays a key role in the process of differentiating retailers and enhancing their perceived image. Now, more than ever, given the increasing attention of individuals to health, which has given rise to new purchasing behaviours (in-store search for products that can meet these needs), it is clear that fruit and vegetables takes on an increasingly important role in the process of choice of store where to buy and at the same time, it constitutes an element on which retailers can build their competitive positioning (Bellini, 2017; Cardinali, 2018).

However, these considerations apply to the offline channel, but raise doubts about the effectiveness of the online channel. It has been seen as the levers of marketing mix such as assortment and merchandising, considered as stimuli capable of influencing the external variables of impulse purchases, are different between offline and online. Thus, it becomes interesting to understand how shoppers behave in buying fruit and vegetables online, if they confirm the quantity, variety and types of purchases. From this starting point, it is possible to frame the current situation in order to identify the online stimuli that can influence the degree of planned and impulse purchases of fruit and vegetables online. Our research focuses on the online channel with the belief that consumers behave differently when buying fruit and vegetables online than the offline channel, preferring more impulse behavior. However, it remains difficult to predict which marketing levers will influence the consumer in making impulse purchases. For these reasons, the purpose of this study is to analyse consumer's behavior in buying fruit and vegetables online. First, we studied people's attitude and interest in the purchase of fruit and vegetable. Second, the research aims to understand the degree of shopping planning and the degree of online impulse buying according to different types of communication and advertising in order to identify which stimuli affect online impulse purchases for fruit and vegetables.

As far as the goals of our research are concerned, we identified the following research questions:

QR1: What the main attitudes and behaviour towards buying fruit and vegetables in the online channel?

QR2: Does pre-shopping preparation affect online fruit and vegetable impulse purchases?

QR3: Which stimuli are more effective in stimulating online impulse purchases of fruit and vegetables?

QR4: Do price levers influence the intention to buy impulsively fruit and vegetables in the online channel? Are price levers less effective than communicative levers in stimulating online impulse purchases of fruit and vegetables?

\section{Methodology}

According to literature review by Chang, Eckman, \& Yan (2011) it was found that, the experiment and questionnaire were the two most widely used research methods to examine online impulse buying. In particular, these two methods have been effective in understanding the different stimuli that trigger impulse buying responses in consumer's attitudes and behaviours.

As far as the experimental approaches, Adelaar et al. (2003) studied the display formats (text, images and videos) of a virtual store and explored their effects on consumers' emotions and impulse purchases. These experimental settings allowed researchers to draw conclusions about the effect of particular website features on impulse purchase.

As far as the survey approach, prior research investigated consumers' perceptions and attitudes towards impulse purchases (Beatty \& Ferrell, 1998; Verhagen \& Van Dolen, 2011; Liu et al., 2013; Bellini et al., 2017; Bellini \& Aiolfi, 2017 and 2019). Therefore, consistent with previous studies we decided to use a quantitative research method based on a structured questionnaire (Sharma, Sivakumaran, \& Marshall, 2010; Mohan et al., 2013; Bellini \& Aiolfi, 2017 and 2019). Data were then analysed through SPSS software and we proposed a descriptive analysis 
before making a linear regression analysis.

\subsection{Sample}

To answer to our research questions, we used a quantitative survey method based on a questionnaire that was self-administered online. Since consumers who surf the Web represent the most suitable target for the research objectives, we requested them to answer to a structured questionnaire trough the online survey software Google Modules. A total of 116 subjects completed the questionnaire and Table 1 illustrates the demographic characteristics of the sample: $68.1 \%$ females and $31.9 \%$ males, with the majority of the respondents $(78.4 \%)$ belonging to the Millennials generational cohort. It is clear that the sample has an overall average education. Among participants, 6 percent have a postgraduate degree, 62.1 percent have a degree, and only 31.95 percent have a higher degree or a middle school degree (see Table 1).

Table 1 - Demographic profile of the sample

\begin{tabular}{lll}
\hline Features & & Percentage \\
\hline \multirow{2}{*}{ Gender } & Females & 68.1 \\
& Males & 31.9 \\
Age group & $20-34$ & 78.4 \\
& $35-65$ & 20.6 \\
& Over 65 years & 1.0 \\
Education & Postgraduate degree & 6.0 \\
& Degree & 62.1 \\
& Secondary school & 29.3 \\
& College & 2.6 \\
\hline
\end{tabular}

\subsection{Procedure}

We first asked online respondents to answer to descriptive questions about their general tendency to shopping and to prepare their shopping expedition. Second, we asked them if they usually buy fruit and vegetables during their grocery shopping expedition, where (in which channel) and why they buy it in order to investigate their buying behavior. Finally, we exposed respondents to nine different stimuli of online visual communications of fruit and vegetables in order to investigate the urgency of consumers to make impulse purchases in an online setting.

The nine stimuli presented in the research are described below:

- Stimulus 1 investigates the individual's behaviour in front of fruits and vegetables at a lower price than other retailers. This stimulus manipulates the price lever;

- Stimulus 2 investigates the behaviour of fruits and vegetables in promotion. As the stimulus 1 , this stimulus is used to investigate the price lever;

- Stimulus 3 features ready-made mixed fruits or vegetables in the box. This is considered as a higher level of service since products are already mixed together and it includes suggested products;

- Stimulus 4 is part of the communicative stimuli and is used to suggest to the consumer a culinary recipe, including the ingredients necessary for the preparation and the steps to be followed;

- Stimulus 5 is part of the communicative stimuli and suggests seasonal products;

- Stimulus 6 is a communicative stimulus and provides nutritional information of products. Specifically, in this case, it is used to promote the healthiest fruits;

- Stimulus 7 represents a high-service product. This stimulus includes, for example, products that have already been washed, cut and bagged;

- Stimulus 8 gives the shopper the ability to view the full range of products available in the assortment;

- Stimulus 9 is an informational label that indicates how products are consumed and stored as well as the degree of maturation of products.

\subsection{Measures}

We measured all the variables considered in the research with multiple-item scales, with Likert measurement scale 
from one (disagree) to seven (agree). Specifically, all scales in the survey come from previous research about shopper and consumer behaviour. Once translated into Italian and adapted for our research to the context of online grocery shopping we considered them for our analysis with an approach similar to prior studies (Bellini et al., 2017; Bellini \& Aiolfi, 2017 and 2019).

Particularly, the degree of pre-shopping preparation was measured using the scale 'Pre-purchase Planning Tendency' proposed by Gauri, Sudhir, and Talukdar (2008), as suggested in Bellini et al. (2017) and Bellini and Aiolfi (2017 and 2019). In addition, consumers 'Urge to purchase' while shopping fruit and vegetables online was measured with the scale of Beatty and Ferrell (1998). Finally, we adapted the scale proposed by Weun, Jones, and Beatty (1998) for this particular research in order to use it to measure the 'Intention to buy impulsively'. Statistical analyses were conducted using SPSS Statistics 24. As for the reliability of the scales, Cronbach's Alpha was analysed and found that all scale values are higher than the minimum acceptance value of 0.70 (Santos, 1999). Consequently, all reliable scales in Table 2 can be considered for our linear regression analysis.

Table 2. Scale summary

\begin{tabular}{|c|c|c|}
\hline Scale & Items & $\begin{array}{l}\text { Cronbach } \\
\text { Alpha }\end{array}$ \\
\hline $\begin{array}{l}\text { Pre-purchase Planning Tendency } \\
\text { (Gauri et al. 2008) }\end{array}$ & $\begin{array}{l}\text { 1. I prepare a shopping list before going grocery shopping } \\
\text { 2. I organize coupons before shopping } \\
\text { 3. I know what products I am going to buy before going to the store } \\
\text { 4. I am a well-organized grocery shopper } \\
\text { 5. Before shopping, I plan my purchases based on the specials available that } \\
\text { week }\end{array}$ & 0.802 \\
\hline $\begin{array}{l}\text { Urge to purchase for Stimulus } 1 \\
\text { (Beatty \& Ferrell, 1998) }\end{array}$ & $\begin{array}{l}\text { 1. Faced with stimulus } 1 \text {, I experienced a number of sudden urges to buy } \\
\text { products that I had not planned before. } \\
\text { 2. Faced with stimulus } 1 \text {, I would notice several products that I would have liked } \\
\text { to buy even if they were not on my list. } \\
\text { 3. Faced with stimulus } 1 \text {, I experienced no strong urge to make unplanned } \\
\text { purchases. }\end{array}$ & 0.861 \\
\hline $\begin{array}{l}\text { Urge to purchase for Stimulus } 2 \\
\text { (Beatty \& Ferrell, 1998) }\end{array}$ & $\begin{array}{l}\text { 1. Faced with stimulus } 2 \text {, I experienced a number of sudden urges to buy } \\
\text { products that I had not planned before. } \\
2 \text {. Faced with stimulus } 2 \text {, I would notice several products that I would have liked } \\
\text { to buy even if they were not on my list. } \\
\text { 3. Faced with stimulus } 2 \text {, I experienced no strong urge to make unplanned } \\
\text { purchases. }\end{array}$ & 0.835 \\
\hline $\begin{array}{l}\text { Urge to purchase for Stimulus } 3 \\
\text { Beatty \& Ferrell, 1998) }\end{array}$ & $\begin{array}{l}\text { 1. Faced with stimulus } 3 \text {, I experienced a number of sudden urges to buy } \\
\text { products that I had not planned before. } \\
2 \text {. Faced with stimulus } 3 \text {, I would notice several products that I would have liked } \\
\text { to buy even if they were not on my list. } \\
\text { 3. Faced with stimulus } 3 \text {, I experienced no strong urge to make unplanned } \\
\text { purchases. }\end{array}$ & 0.785 \\
\hline Urge to purchase for Stimulus 4 & $\begin{array}{l}\text { 1. Faced with stimulus } 4 \text {, I experienced a number of sudden urges to buy } \\
\text { products that I had not planned before. } \\
2 \text {. Faced with stimulus } 4 \text {, I would notice several products that I would have liked } \\
\text { to buy even if they were not on my list. } \\
\text { 3. Faced with stimulus } 4 \text {, I experienced no strong urge to make unplanned } \\
\text { purchases. }\end{array}$ & 0.830 \\
\hline $\begin{array}{l}\text { Urge to purchase for Stimulus } 5 \\
\text { (Beatty \& Ferrell, 1998) }\end{array}$ & $\begin{array}{l}\text { 1. Faced with stimulus } 5 \text {, I experienced a number of sudden urges to buy } \\
\text { products that I had not planned before. } \\
2 \text {. Faced with stimulus } 5 \text {, I would notice several products that I would have liked } \\
\text { to buy even if they were not on my list. } \\
3 \text {. Faced with stimulus } 5 \text {, I experienced no strong urge to make unplanned } \\
\text { purchases. }\end{array}$ & 0.850 \\
\hline $\begin{array}{l}\text { Urge to purchase for Stimulus } 6 \\
\text { (Beatty and Ferrell, 1998) }\end{array}$ & $\begin{array}{l}\text { 1. Faced with stimulus } 6 \text {, I experienced a number of sudden urges to buy } \\
\text { products that I had not planned before. } \\
\text { 2. Faced with stimulus } 6 \text {, I would notice several products that I would have liked }\end{array}$ & 0.783 \\
\hline
\end{tabular}




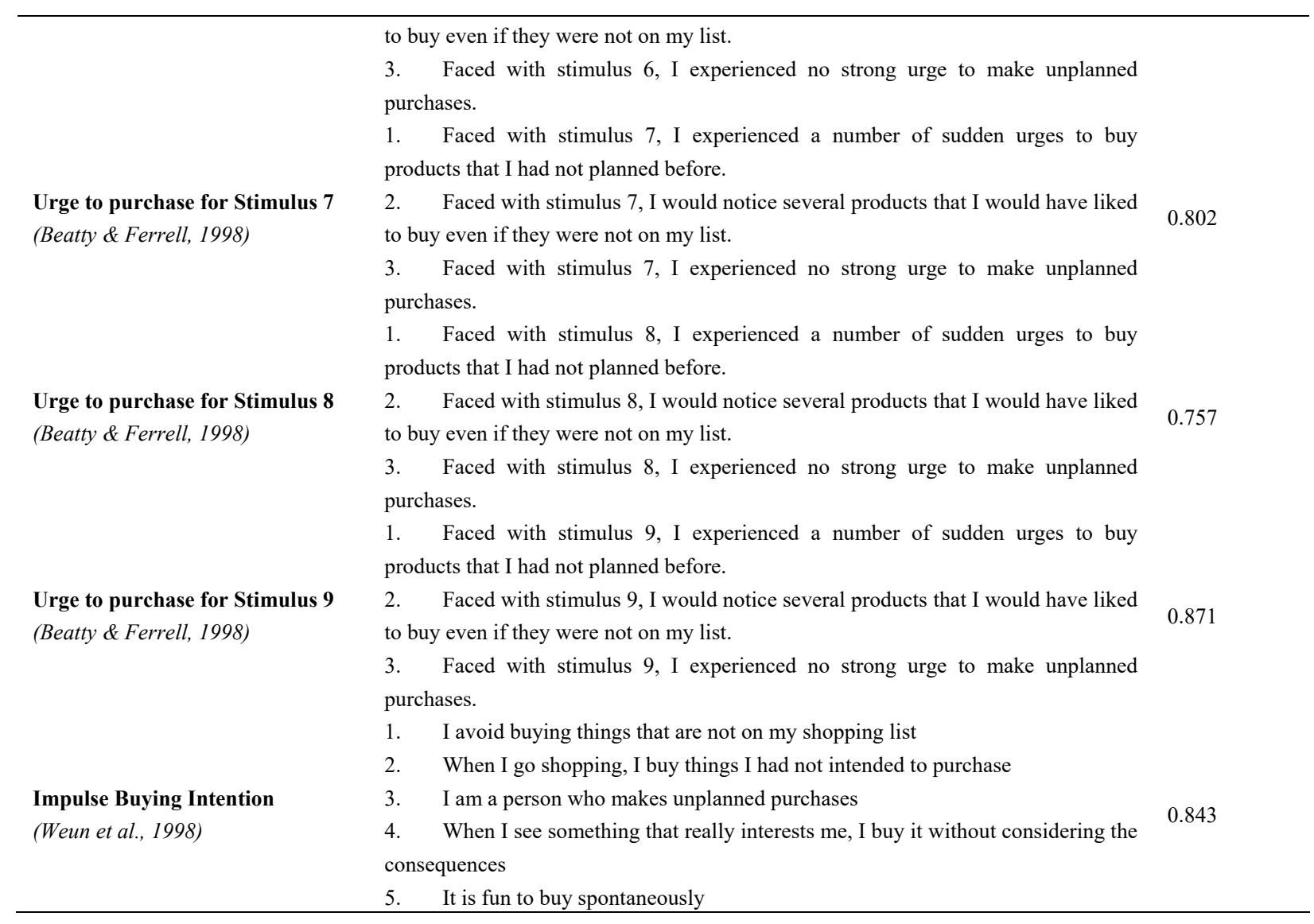

\section{Findings and Discussion}

Initially, descriptive analyses show that 70.7 per cent of the sample bought fruit and vegetables at the supermarket, 15.5 per cent went to a specialty store, more than 8 per cent bought fruit and vegetables at the local market and the remaining part prefer to go to a convenience store near home (see Table 3 ).

Table 3. Fruit and vegetables: channel choice

\begin{tabular}{lcc}
\hline Where do you buy fruit and vegetables? & Frequency & Percentage \\
\hline Convenience store near home & 6 & $5.2 \%$ \\
Local Market & 10 & $8.6 \%$ \\
Specialty Store & 18 & $15.5 \%$ \\
Supermarket & 82 & $70.7 \%$ \\
Total & 116 & $100.0 \%$ \\
\hline
\end{tabular}

Interestingly, confirming market trends, fruits and vegetables are products present in the diet of the Italians. In fact, more than 56 percent of the respondents stated to buy fruit and vegetables several times a week, and 33.6 percent once a week. Only 6 percent bought it once a month (see Table 4). 
Table 4. Fruit and vegetables: purchase frequency

\begin{tabular}{lcc}
\hline How frequent do you buy fruit and vegetables? & Frequency & Percentage \\
\hline Never & 4 & $3.4 \%$ \\
Once a week & 39 & $33.6 \%$ \\
Several times a week & 66 & $56.9 \%$ \\
Once a month & 7 & $6.0 \%$ \\
Total & 116 & $100.0 \%$ \\
\hline
\end{tabular}

The main motivation for buying fruit and vegetables is that individuals like them as food products (44.5\%) followed by the fact that they consider fruits and vegetables as products good for health $(28.3 \%)$. Purchases are also justified by the fact that fruit and vegetables allow to vary the nutritional diet (20.8\%) (see Table 5).

Table 5. Fruit and vegetables: purchase motivation

\begin{tabular}{lcc}
\hline Why do you buy fruit and vegetables? & Frequency & Percentage \\
\hline It's good for health & 49 & $28.3 \%$ \\
To vary my diet & 36 & $20.8 \%$ \\
I am following a diet & 11 & $6.4 \%$ \\
I like fruit and vegetables & 77 & $44.5 \%$ \\
Total & 173 & $100.0 \%$ \\
\hline
\end{tabular}

By descriptive statistics, it was possible to obtain a ranking of the most impactful stimuli on consumers' perceptions. Table 6 shows how the stimulus that had the most impact on 'Urge to purchase' is stimulus 5 that is related to the promotion and suggestion of seasonal products. This was followed by stimulus 9 representing products accompanied by an information label regarding the way of consumption and the degree of maturation of the product. Then, the stimulus 6 on nutritional information of products and the stimulus 4 , which suggested a culinary recipe and necessary ingredients. The stimulus that has the least impact on the 'Urge to purchase' is the stimulus 3, the one that presented the fruit already placed in the box. Of course, these considerations answer to QR3 but since they refer to descriptive analyses, the degree of statistical significance cannot be detected.

Table 6. Ranking of Urge to purchase means related to the nine stimuli

\begin{tabular}{clcc}
\hline \multicolumn{1}{c}{ Sanking } & \multicolumn{1}{c}{ Stimulus } & Mrge to purchase & Standard Deviation \\
& & 5.124 & 1.710 \\
$1^{\circ}$ & 5 - seasonal products & 4.845 & 1.845 \\
$2^{\circ}$ & 9 - informational label & 4.649 & 1.629 \\
$3^{\circ}$ & 6 - nutritional information & 4.551 & 1.748 \\
$4^{\circ}$ & 4 - recipe & 4.324 & 1.840 \\
$5^{\circ}$ & 1 - lower price vs competitor & 4.192 & 1.474 \\
$6^{\circ}$ & 8 - in-store display & 4.164 & 1.739 \\
$7^{\circ}$ & 2 - promotion & 3.773 & 1.546 \\
$8^{\circ}$ & 7 - high-service product & 3.767 & 1.633 \\
$9^{\circ}$ & 3 - fruits and vegetables in boxes & \\
\hline
\end{tabular}

Furthermore, to relate stimuli to impulse buying intention, we proceeded by performing a multiple linear regression, defining 'Impulse Buying Intention' as the dependent variable while 'Urge to purchase', declined for all the nine stimuli, and the 'Pre-purchase Planning Tendency' were considered as independent variables.

The regression model presented in Table 7 was good with a value of $\mathrm{F}=6.762$ (p-value $<0.000$ ). 
Table 7. Regression model with all the nine stimuli

\begin{tabular}{|c|c|c|c|c|c|}
\hline \multirow{2}{*}{ Model* } & \multicolumn{2}{|c|}{$\begin{array}{l}\text { Unstandardized } \\
\text { Coefficients }\end{array}$} & \multirow{2}{*}{$\begin{array}{l}\text { Standardized } \\
\text { Coefficients }\end{array}$} & \multirow[t]{2}{*}{$\mathbf{t}$} & \multirow[t]{2}{*}{ Sig. } \\
\hline & B & Std. Error & & & \\
\hline (Constant) & 3.007 & .662 & & 4.544 & .000 \\
\hline Pre-purchase Planning Tendency & -.446 & .091 & -.446 & -4.895 & .000 \\
\hline Urge to purchase_Stimulus1 & .100 & .127 & .137 & .793 & .429 \\
\hline Urge to purchase_Stimulus2 & .022 & .132 & .029 & .169 & .866 \\
\hline Urge to purchase_Stimulus3 & .082 & .082 & .099 & .996 & .321 \\
\hline Urge to purchase_Stimulus4 & .223 & .088 & .289 & 2.524 & .013 \\
\hline Urge to purchase_Stimulus5 & .081 & .098 & .103 & .831 & .408 \\
\hline Urge to purchase_Stimulus6 & -.032 & .092 & -.039 & -.349 & .728 \\
\hline Urge to purchase_Stimulus7 & .140 & .079 & .160 & 1.768 & .080 \\
\hline Urge to purchase_Stimulus8 & .077 & .079 & .084 & .977 & .331 \\
\hline Urge to purchase_Stimulus9 & .000 & .083 & -.001 & -.006 & .996 \\
\hline
\end{tabular}

Note. * Model summary: dependent variable=Impulse Buying Intention; R=.626; R Square=.392; Adjusted R Square=.334; Std. Error of the Estimate $=1.102 ; \mathrm{F}=6.762 ; \mathrm{P}$-value $=0.000$.

As far as the regression coefficients, the "Pre-purchase Planning Tendency" is significant and it shows a negative relationship with the 'Impulse buying intention' $(\beta=-0.446$, $p$-value $<0.05)$ : if consumers devote time to their pre-shopping preparation, the level of their intention to buy impulsively decreases. There is also a positive and significant relation between 'Urge to purchase' of stimulus 4, which is related to the recipe, and the dependent variable 'Intention to buy impulsively' $(\beta=0.289$, $p$-value $<0.05$ ). Moreover, 'Urge to purchase' of stimulus 7 that concerns high-service products, is positive related to the 'Impulse buying intention' $(\beta=0.160$, $p$-value $<0.1)$. All the other stimuli are not statistical significant.

Subsequently, with the aim of investigating the variables affecting intention to buy impulsively, we decided to categorize the nine stimuli into two macro areas: stimuli related to price and stimuli related to communication and promotion. We included stimulus 1 and stimulus 2 in the 'price stimuli', while stimuli 4, 5, 6 and 9 were classified in the 'communicative stimuli'.

Compared to the previous model, the new regression model in Table 8 fit well with a value $\mathrm{F}=16.456$ ( $\mathrm{p}$-value $<0.000$ ) higher than the previous one.

Table 8. Regression Model with price stimuli and communicative stimuli

\begin{tabular}{|c|c|c|c|c|c|}
\hline \multirow[t]{2}{*}{ Model* } & \multicolumn{2}{|c|}{$\begin{array}{l}\text { Unstandardized } \\
\text { Coefficients }\end{array}$} & \multirow{2}{*}{$\begin{array}{l}\text { Standardized } \\
\text { Coefficients } \\
\text { Beta }\end{array}$} & \multirow[t]{2}{*}{$\mathbf{t}$} & \multirow[t]{2}{*}{ Sig. } \\
\hline & B & Std. Error & & & \\
\hline (Constant) & 3.471 & .643 & & 5.401 & .000 \\
\hline Pre-purchase Planning Tendency & -.488 & .090 & -.488 & -5.456 & .000 \\
\hline Price stimuli & .196 & .067 & .253 & 2.926 & .004 \\
\hline Communicative Stimuli & .389 & .084 & .417 & 4.615 & .000 \\
\hline
\end{tabular}

* Model summary: dependent variable=Impulse Buying Intention; R=.553; R Square=.306; Adjusted R Square=.287; Std. Error of the Estimate $=1.139 ; \mathrm{F}=16.456 ; \mathrm{P}$-value $=0.000$

As far as the regression results, the dependent variable 'Impulse Buying Intention' is related to both the 'Pre-Purchase Planning Tendency' and the 'price stimuli' as well as the 'communicative stimuli'.

Specifically, the results show a significant negative relationship between 'Pre-Purchase Planning Tendency' and 
'Impulse Buying Intention' $(\beta=-0,488, p$-value $<0.05)$ : an increase in the pre-shopping activities reduces the intention to buy on impulse. In addition, as far as 'price stimuli' and 'communicative stimuli', the model shows that the price is positive related to 'Impulse Buying Intention' $(\beta=0.253, p$-value $<0.05)$ but less than the communication ( $\beta=0.417$, $p$-value $<0.05$ ). Therefore, in addition to the negative effect of the preparation activity, what emerges is the dual influence of 'price stimuli' and 'communicative stimuli' on the intention to buy on impulse in the online channel as far as fruit and vegetables. However, the effect of communicative stimuli remains predominant.

While it may seem contradictory that both stimuli have an effect on impulse buying intention, it should be remembered that in the online channel price plays a larger role than the offline channel. Specifically, as far as fruit and vegetables, the price in the offline channel does not have the same impact on impulse purchase as in the online channel where the price has a certain impact, although less than that of the communicative stimuli.

To sum up, as far as the first question research (QR1), aimed at studying people's attitude and interest in the purchase of fruit and vegetable products, results show how interest and frequency of purchase towards the fruit and vegetables is predominant. In addition, as far as the second question research (QR2), it is verified that pre-purchase preparation tendency negatively affects online impulse purchases. As far as the third question research (QR3), the stimuli that contribute more to the urgency of buying is stimulus 5 , related to the suggestion of seasonal products. This is followed first by stimulus 9 , regarding information labels about the possibility of consumption and the degree of maturation of products, and second by the stimulus 6 about the nutritional information of products. Moreover, the stimulus 3, with fruit and vegetables already placed in a box, has the least impact on the urge to purchase. Finally, as far as the fourth question research (QR4), the data provided by the two multiple linear regression models confirm that price levers influence the intention to buy on impulse online. Specifically, price levers are less effective than communicative levers to stimulate online impulse purchases for fruit and vegetables.

\section{Conclusions and Managerial Implications}

The results of the proposed study confirm the role that online plays and will play in the future, both for retailers and people own lives. Innovation in content and extension of strategic horizons are the keys to success for retailers. Competition is moving towards an Omni channel world, where maintaining a distinctive positioning in the consumer's mind becomes increasingly difficult. It is crucial to understand in which direction the demand is moving to reach consumers among different channels. The focus of retailers now should be on the shopper's buying behaviour, tracing the new emerging lifestyles, which today concern an increasing pre-shopping preparation and an increasing interest in health and nutrition issues. Specifically, there are several studies that demonstrate the relationship between fruit and vegetables consumption and health benefits, in terms of controlling obesity, preventing chronic diseases and cancers. From the data collected it is clear that the growing demand for fruits and vegetables represents an opportunity that should be stressed by retailers, both offline and online.

This work highlights how it is necessary for retailers to innovate their overall marketing strategies by rethinking the logic of conditioning individuals both outside and inside the store. Our research on fruit and vegetables shows that the process of preparing the shopping expedition before entering the online or offline store has an effect on purchasing behaviour, limiting its impulsiveness. As this process takes on further strength in the digital context, marketing efforts need to focus on dimensions that increase the propensity to make impulse purchases online: communicative and price stimuli.

In fact, both price levers and communication levers influence the intention to buy impulse in the online channel, with the latter more effective than the other ones. This confirms how communication and nutritional marketing are the best performing levers. Specifically, our analysis identifies the seasonality of products, the information component about consumption and maturation of products and finally the nutritional information as main variables effecting the urgency to purchase fruit and vegetables.

As far as managerial implications, these results could be used as a starting point for implementing innovative strategies in the online channel. Since, fruit and vegetable is known for its healthy vocation and its role in differentiating and enhancing the perceived image of retailers, this category is the ideal place to host nutritional marketing initiatives. The growing focus on health has given rise to new purchasing behaviours that result in in-store research of products and solutions that meet these needs. As a result, from a strategic point of view, a retailer aware that both price stimuli and communicative stimuli are able to influence impulse purchases can result in a more conscious management of marketing levers and a more profitable use of the online channel. However, this is not enough.

Specifically, in order to have a good presence on the online environment, it is appropriate for retailers to enrich their website with new features enhancing the simplicity of purchasing procedures (e.g. 'basket' or 'shopping list' 
gradually updated with the total amount of the selected products to facilitate purchase processes from a cognitive point of view). Companies should also create a safe and trusted environment through innovative and easy payment systems. This will be possible thanks to partnerships with agents that ensure transaction security (e.g. PayPal ) or thanks to the use security protocols (e.g. a request for credit card information at the initial registration and subsequent use of the user's identification password).

In addition, retailers should integrate the online transaction with offline media in order to increase the control of the environment. For example, they should encourage the ability to monitor the physical journey of products purchased online through a notification via text message; they should create both call center run by company staff and other local touch points where consumers can withdraw the product physically, with a discount on delivery costs. Finally, one of the possible ways to maintain the consumer's interest in the retail environment, preventing the retailers from returning to a role of pure delivery of products and services, is the experiential enhancement of the purchasing process.

\section{Limitations and Future Research}

Despite the theoretical and managerial contributions, the proposed research has some limitations. In particular, the reduced sample prevents the generalizability of the results and the possibility of an in-depth analysis. Another limitation is the way in which the questionnaire was disclosed. In fact, although self-administration has reduced costs and possible distortions and ensured the comfort of the respondent and anonymity, it is inherently the cause of some potential problems. Among them, the main one is that the sample is self-selected, because, inevitably, only those who are motivated answer. A further pitfall is related to the total lack of relationship and control during the compilation phase, which can result in errors and misunderstandings by respondents.

In addition, the study identified only some of the external determinants of impulse purchases, investigating only the cognitive dimension. For future research, one might think of conducting experiments and investigating the effect of variables on impulse buying by simulating a real online purchase. In this way, it would be possible to better isolate variables and consider others. Finally, further research might focus on robust statistics methods. For example, we could apply a structural equation modelling approach.

\section{References}

Abratt, R., \& Goodey, S. D. (1990). Unplanned buying and in-store stimuli in supermarkets. Managerial and Decision Economics, 11(2), 111-121.

Adelaar, T., Chang, S., Lancendorfer, K. M., Lee, B., \& Morimoto, M. (2003). Effects of media formats on emotions and impulse buying intent. Journal of Information Technology, 18(4), 247-266.

Aiolfi, S., \& Sabbadin, E. (2017). The new paradigm of the omni channel retailing: key drivers, new challenges and potential outcomes resulting from the adoption of an omni channel approach. International Journal of Business and Management, 13(1), 85.

Beatty, S. E., \& Ferrell, M. E. (1998). Impulse buying: modeling its precursors. Journal of Retailing, 74(2), 169-191. http://dx.doi.org/10.1016/s0022-4359(99)80092-x

Beck, N., \& Rygl, D. (2015). Categorization of multiple channel retailing in Multi-, Cross-, and Omni-Channel Retailing for retailers and retailing. Journal of Retailing and Consumer Services, 27, 170-178. https://doi.org/10.1016/j.jretconser.2015.08.001

Bell, D., Corsten, D., \& Knox, G. (2011). From point of purchase to path to purchase: how preshopping factors drive unplanned buying. Journal of Marketing, 75, 31-45. http://dx.doi.org/10.1509/jmkg.75.1.31

Bellenger, D., Robertson, D., \& Hirschman, E. (1978). Impulse buying varies by product. Journal of Advertising Research, 18(6), 15-18.

Bellini, S., \& Cardinali, M. G. (2015). A consumer perspective on grocery retailers' differentiation. International Business Research, 8(8), 129-140.

Bellini, S. (2017). Channel Relationship (R)Evolution. Come cambiano le relazioni di canale nel contest di convergenza e omnicanalità. EGEA, Milano.

Bellini, S., \& Aiolfi, S. (2017). The impact of mobile device use on shopper behaviour in store: an empirical research on grocery retailing. International Business Research, 10(4), 58-68. http://dx.doi.org/10.5539/ibr.v10n4p58

Bellini, S., \& Aiolfi, S. (2019). Impulse buying behavior: the mobile revolution. International Journal of Retail \& Distribution Management, 40(1), 1-17. 
Bellini, S., Cardinali, M. G., \& Grandi, B. (2016). Does shopping preparation influence consumer buying decisions? International Business Research, 9(10). http://dx.doi.org/10.5539/ibr.v9n10p201

Bellini, S., Cardinali, M. G., \& Grandi, B. (2017). A structural equation model of impulse buying behaviour in grocery retailing. Journal of Retailing and Consumer Services, 36, 164-171. https://doi.org/10.1016/j.jretconser.2017.02.001

Block, L., \& Morwitz, V. (1999). Shopping list as an external memory aid for grocery shopping: influences on list writing and list fulfilment. Journal of Consumer Psychology, 8(4), 343-375. http://dx.doi.org/10.1207/s15327663jcp0804_01

Brynjolfsson, E., Hu, Y. J., \& Rahman, M. S. (2013). Competing in the age of omnichannel retailing. MIT.

Cardinali, M. G., \& Bellini, S. (2014). Interformat competition in the grocery retailing. Journal of Retailing and Consumer Services, 21, 438448.

Cardinali, M. G. (2018). Retail ibrido. EGEA, Milano.

Cardinali, M. G. (2009). Shopper marketing. Egea, Milano.

Casagrande, S. S., Wang, Y., Anderson, C., \& Gary, T. L. (2007). Have Americans increased their fruit and vegetable intake? American Journal of Preventive Medicine, 32(4), 257-63.

Chan, T. K., Cheung, C. M., \& Lee, Z. W. (2017). The state of online impulse-buying research: A literature analysis. Information \& Management, 54(2), 204-217.

Chang, H. J., Eckman, M., \& Yan, R.N. (2011). Application of the Stimulus-Organism-Response model to the retail environment: the role of hedonic motivation in impulse buying behaviour. The International Review of Retail, Distribution and Consumer Research, 21(3), 233-249.

Dantoni, J. J. S., \& Shenson, H. L. (1973). Impulse buying revisited: a behavioral typology. Journal of Retailing, $49(1), 63-76$.

Donovan, R. J., Rossiter, J. R., Marcoolyn, G., \& Nesdale, A. (1994). Store atmosphere and purchasing behavior. Journal of Retailing, 70(3), 283-294. http://dx.doi.org/10.1016/0022-4359(94)90037-X

Engel, J. F., \& Blackwell, R. D. (1982). Consumer behaviour. Dryden Press, Chicago.

Gauri, D. K., Sudhir, K., \& Talukdar, D. (2008). The temporal and spatial dimensions of price search: insights from matching household survey and purchase data. Journal of Marketing Research, 45(2), 226-240. https://doi.org/10.1509/jmkr.45.2.226

Gwee, M. Y. T., \& Chang, K. T. T. (2013). Effects of persuasive claims on desirability and impulse purchase behaviour. Americas Conference on Information Systems (pp. 1-7). Chicago, Illinois.

Halpern, D. F. (1989). Thought and knowledge: an introduction to critical thinking. New York: Psychology Press.

Han, Y. K., Morgan, G. A., Kotsiopulo, A., \& Kang-Park, J. (1991). Impulse buying behavior of apparel purchasers. Clothing and Textiles Research Journal, 9(3), 15-21. http://dx.doi.org/10.1177/0887302X9100900303

Herhausen, D., Binder, J., Schoegel, M., \& Herrmann, A. (2015). Integrating bricks with clicks: retailer-level and channel-level outcomes of online-offline channel integration. Journal of Retailing, 91(2), 309-325. https://doi.org/10.1016/j.jretai.2014.12.009

Hirschman, E. C., \& Holbrook, M. B. (1982). Hedonic consumption: emerging concepts, methods and propositions. The Journal of Marketing, 46(3), 92-101. http://dx.doi.org/10.2307/1251707

Hoch, S., \& Loewenstein, J. (1991). Time-Inconsistent Preferences and Consumer Self-Control. Journal of Consumer Research, 17(4), 492-507. http://dx.doi.org/10.1086/208573

Hosmer, D. W., \& Lemeshow, S. (1989). Applied Logistic Regression. New York: John Wiley \& Sons, Inc.

Hulten, P., \& Vanyushyn, V. (2011). Impulse purchases of groceries in France and Sweden. Journal of Consumer Marketing, 28(5), 376-384. http://dx.doi.org/10.1108/07363761111150026

Inman, J. J., Winer, R. S., \& Ferraro, R. (2009). The interplay among category characteristics, customer characteristics, and customer activities on in-store decision making. Journal of Marketing, 73(5), 19-29. http://dx.doi.org/10.1509/jmkg.73.5.19

Iyer, E. S. (1989). Unplanned purchasing: Knowledge of shopping environment and time pressure. Journal of 
Retailing, 65(1), 40-57.

Iyer, E., \& Ahlawat, S. (1987). Deviation from a shopping plan: when and why do consumers not buy items as planned. Advances in Consumer Research, 14, 246-250. http://acrwebsite.org/volumes/6696/volumes/v14/NA-14

Kacen, J. J., \& Lee, J. A. (2002). The influence of culture on consumer impulsive buying behavior. Journal of Consumer Psychology, 12(2), 163-176.

Kollat, D., Willett, R. (1967). Customer impulse purchasing behavior. Journal of Marketing Research, 4, 21-31. http://dx.doi.org/10.2307/3150160

Lee, J. A., Kacen, J. J. (2008). Cultural influences on consumer satisfaction with impulse and planned purchase decisions. Journal of Business Research, 61, 265-272.

Lewis, J., Foster, C., \& Whysall, P. (2013). Understanding the issues associated with going multi-channel: preliminary findings from an exploratory study in the UK retail sector. 17th EAERCD conference.

Liu, Y., Li, H., \& Hu, F. (2013). Website attributes in urging online impulse purchase: an empirical investigation on consumer perceptions. Decision Support Systems, 55(3), 829-837.

Lugli, G. (2015). Cibo, salute e business. Neuroscienze e marketing. EGEA, Milano.

Moe, W. W. (2003). Buying, searching, or browsing: differentiating between online shoppers using in-store navigational clickstream. Journal of Consumer Psychology, 13(1), 29-39.

Mohan, G., Sivakumaran, B., \& Sharma, P. (2013). Impact of store environment on impulse buying behavior. European Journal of Marketing, 47(10), 1711-1732. http://dx.doi.org/10.1108/ejm-03-2011-0110

Muruganantham, G., \& Bhakat, R. S. (2013). A review of impulse buying behavior. International Journal of Marketing Studies, 5(3), 149.

Payne, C. R., Niculescu, M., Just, D. R., \& Kelly, M. P. (2014). Shopper marketing nutrition interventions. Physiology \& Behavior, 136, 111-120.

Payne, C. R., \& Niculescu, M. (2012). Social meaning in supermarkets as a direct route to improve parents' fruit and vegetable purchases. Agricultural and Resource Economics Review, 41(1), 124-37.

Raju, K. V., Kumar, D. P., \& Raju, S. S. (2015). A comprehensive review of impulse purchase process and various factors affecting it. IOSR Journal of Business and Management (IOSR-JBM), 17(12), 81-107.

Rangaswamy, A., \& Van Bruggen, G. H. (2005). Opportunities and challenges in multichannel marketing: An introduction to the special issue. Journal of Interactive Marketing, 19(2), 5-11.

Rook, D. W. (1987). The buying impulse. Journal of Consumer Research, 14(2), 189-197. http://dx.doi.org/10.1086/209105

Rook, D. W., \& Fisher, R. J. (1995). Normative influences on impulsive buying behavior. The Journal of Consumer Research, 22(3), 305-313. http://dx.doi.org/10.1086/209452

Rook, D. W., \& Gardner, M. P. (1993). In the mood: impulse buying's affective antecedents. Research in Consumer Behavior, 6(7), 1-28.

Santos, J. R. A. (1999). Cronbach's Alpha: a tool for assessing the reliability of scales. Journal of Extension, $37(2), 1-5$.

Shankar, V. (2011). Shopper Marketing. Cambridge, Massachusetts: Marketing Science Institute.

Shankar, V. (2014). Shopper marketing 2.0: opportunities and challenges. Review of Marketing Research, 11, 189-208. http://dx.doi.org/10.1108/s1548-643520140000011007

Sharma, P., Sivakumaran, B., \& Marshall, R. (2010). Impulse buying and variety seeking: A trait-correlates perspective. Journal of Business Research, 63(3), 276-283.

$\begin{array}{lllll}\text { Statista } & \text { (2020). } & \text { eCommerce } & \text { report } & \text { Retrieved from }\end{array}$ https://www.statista.com/study/42335/ecommerce-report/

Stern, H. (1962). The significance of impulse buying today. The Journal of Marketing, 26(2), 59-62. http://dx.doi.org/10.2307/1248439

Strang, R. (2013). Retail without boundaries. Supply Chain Management Review, 17(6).

Talukdar, D., \& Lindsey, C. (2013). To buy or not to buy: consumers' demand response patterns for healthy 
versus unhealthy food, Journal of Marketing, 77(2), 124-138.

Tinne, W. S. (2010). Impulse purchasing: a literature overview. ASA University Review, 4(2), 65-73.

Venkateswara, R. K., Kumar, P. D., \& Srinivasa, R. (2015). A comprehensive review of impulse purchase process and various factors affecting it. Journal of Business and Management, 17(12), 81-107.

Verhagen, T., \& Van Dolen, W. (2011). The influence of online store beliefs on consumer online impulse buying: A model and empirical application. Information \& Management, 48, 320-327.

Verhoef, P. C., Kannan, P. K., \& Inman, J. J. (2015). From multi-channel retailing to omni-channel retailing introduction to the special issue on multi-channel retailing. Journal of Retailing, 91(2), 174-181.

Weun, S., Jones, M. A., \& Beatty, S. E. (1998). Development and validation of the impulse buying tendency scale. Psychological Reports, 82(3_suppl), 1123-1133.

Wiese, A., Zielke, S., \& Toporowski, W. (2015). Shopping travel behaviour: influencing factors, shopper types and environmental consequences. International Journal of Retail \& Distribution Management, 43(4/5), $469-484$.

Zhang, D., Zhou, L., Uchidiuno, J. O., \& Kilic, I. Y. (2017). Personalized assistive web for improving mobile web browsing and accessibility for visually impaired users. ACM Transactions on Accessible Computing (TACCESS), 10(2), 1-22.

\section{Copyrights}

Copyright for this article is retained by the author(s), with first publication rights granted to the journal.

This is an open-access article distributed under the terms and conditions of the Creative Commons Attribution license (http://creativecommons.org/licenses/by/4.0/). 